\title{
Improvisation Analysis of Reactive Power Energy Saving Lamps Based on Inverter
}

\author{
Zuraidah Tharo ${ }^{1}$, Andysah Putera Utama Siahaan ${ }^{2}$, Noorly Evalina ${ }^{3}$ \\ ${ }^{1}$ Faculty of Engineering, ${ }^{2}$ Faculty of Computer Science, ${ }^{2}$ Faculty of Engineering \\ Universitas Pembangunan Panca Budi \\ J1. Jend. Gatot Subroto Km. 4,5 Sei Sikambing, 20122, Medan, Sumatera Utara, Indonesia \\ ${ }^{3}$ Universitas Muhammadiyah Sumatera Utara \\ ${ }^{3}$ Jalan Kapten Mucthar Basri No. 3, 20238, Medan, Sumatera Utara, Indonesia
}

\begin{abstract}
:
To solve the loss of power in the household, we need a tool that is capable of supplying the power source voltage. One of the tools is the inverter, so the author aims to analyze how the effects of the use of the appliance inverter if saddled with the burden of energy-saving lamps as lighting in residences. The method used is by measuring along with an analysis of calculation given load whenever inverter energysaving lamps with varying power to determine the change in the electrical quantities to be analyzed. This research reached at the time of getting the highest load of $203 \mathrm{~W}$; $\cos \varphi$ light weight using the inverter much better, reaching 0.93 compared without using an inverter which is just 0.68 as well as current and load power consumed by the use of the much smaller inverter. For example, only $0,76 \mathrm{~A}$ and $135,63 \mathrm{~A}$ compared to the load current and power without the use of inverters that achieve 1,3A and $185,64 \mathrm{~W}$.
\end{abstract}

\section{Keywords - Inverter, Saving Lamp, Load Power.}

\section{INTRODUCTION}

Advances in technology are evolving rapidly cause electric resource needs will increase. If the supply of electrical power provided by the power source is not sufficient, it will cause the deficit of energy that can result in blackouts in the rotation to compensate the shortfall of electric energy. Power outages also caused by disturbances in the electrical grid system so that the source of the electricity to consumers disconnected. To cope with power outages, especially households, it is necessary to have an emergency equipment that can distribute electrical power while working as a substitute supply of electricity. The tools used are an inverter, which is an electronic device that can convert direct current emanating from devices such as batteries, accumulators or solar cells into alternating electric current. This tool can work with backup electricity at home within a particular time (temporarily) when the supply of power goes out and as long as the input voltage of the battery was not depleted. The source voltage of the inverter is the battery or batteries and is only used when needed or as a temporary replacement. The consumers are not hampered in their daily activities at home, especially regarding electricities.

\section{THEORIES}

\section{A. Inverter}

The inverter is a circuit to convert DC into AC voltage output as desired. Alternating voltage waveform square and on the particular application required the filter to produce a sinusoidal waveform. Great setting voltage can do in two ways. First by regulating the DC input voltage from the outside but the width of fixed ignition timing and setting the width switching time with the DC input voltage remains [2].

Inverter consists of the primary circuit formed by the rectifier circuit whether controlled or not to convert the alternating current into direct current and eliminates the ripple contained on direct current 
[3][4]. It is connected by good circuit and wires [7]. The rectifier serves as a charger voltage on the battery or accumulator when the voltage source inverter which comes from the battery has run out. To prevent damage to the battery due to overcharge, an automatic circuit rectifier circuit must be added to decide the filling process when the voltage on the battery is full. The following figure shows the inverter model.

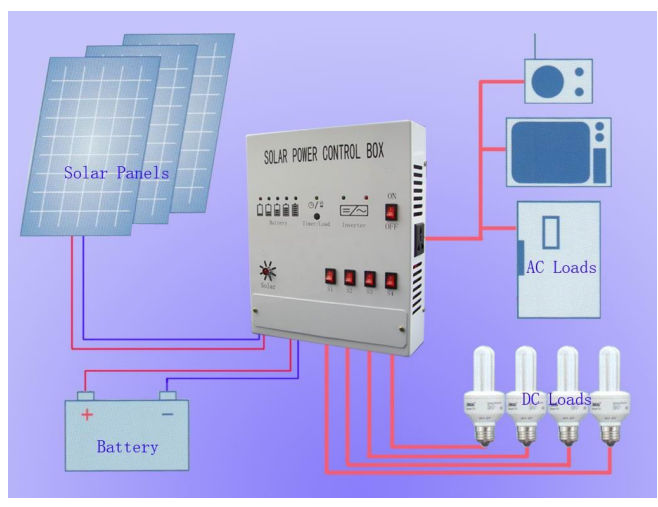

Fig.1 Inverter Scheme

\section{B. Full-Bridge Converter Theory}

Full-Bridge Converter Theory is the basic theory to convert DC to $\mathrm{AC}$. It has a pair switch $(\mathrm{C} 1, \mathrm{C} 2)$ and $(\mathrm{C} 3, \mathrm{C} 4)$. AC output is obtained from a DC input to open and close switches in the proper order. The output voltage is positive, negative or zero. Note that $\mathrm{C} 1$ and $\mathrm{C} 4$ should not be shut down at the same time, as well as the $\mathrm{C} 2$ and $\mathrm{C} 3$, which will cause a short circuit on the source DC. Real switch that could not get on or off instantly. The output voltage of the condition of the pair switch on the circuit full bridge converter is shown in Table 1 .

Table 1 Output voltage

\begin{tabular}{|c|c|c|}
\hline No. & Close Circuit & Voltage \\
\hline 1 & $\mathrm{C} 1$ and $\mathrm{C} 2$ & + \\
\hline 2 & $\mathrm{C} 3$ and $\mathrm{C} 4$ & - \\
\hline 3 & $\mathrm{C} 1$ and $\mathrm{C} 3$ & 0 \\
\hline 4 & $\mathrm{C} 2$ and $\mathrm{C} 4$ & 0 \\
\hline
\end{tabular}

\section{Inverter Types}

Based on the total phase, the inverter can divide into two categories, single and three phase. Based on an inverter circuit configuration, it is also distinguished by two types, single phase half bridge, and single phase full bridge inverter. Based on the waveform, inverters are categorized into three groups, shaped square, modified sine, and true sine wave. The inverter is best able to produce a pure sinusoidal wave or true sine wave that is the same waveform with the waveform of the electrical network from the power source [5][6].

\section{Methodology}

This study uses an experimental method of case plan until testing of the inverter used.

The equipment utilized in this study are as follows:

1. Inverter single phase, as transformers DC to AC that will be considered use.

2. Energy Saving Lamp type SL, an electrical load that will burden the inverter which these lights arranged in parallel and power consumption, varies widely.

3. Accumulator, as a DC voltage source to power the inverter.

4. Rectifier (charger), are used as auxiliary equipment when required for charging the battery voltage.

5. Ammeter AC and DC used to measure the flow of inputs and outputs on the circuit.

6. Multimeter used to gauge the voltage on the circuit and its frequency.

7. Electronic energy meter used as a measure of power and cos phi load.

8. Jumper cables, as the connector terminals on the circuit.

9. Camera (mobile), used to perpetuate research on the indicators to be studied.

In this study, the object or variable research is to observe the effect of changing the amount of light power charged to the inverter that generated the data or indications that the objectives of this study. 
Data research will cover some points; it is included as shown in the following steps:

a. Data testing of ignition inverter circuit that includes measurement waveforms using a digital oscilloscope on wave height, wave width, time / div, volt / div and scale of probe used.

b. Data testing of inverters without the burden of covering the measurement of the magnitude of the input voltage, output voltage, input current and the output current at the inverter.

c. Data load testing of inverters with energysaving lamps, including measurement of the magnitude of the input voltage, output voltage, input current, output current, frequency and power factor on the inverter.

d. Test data to an inverter which includes the calculation of the amount of input power, active power, apparent power, reactive power and efficiency of the inverter.

e. Data testing of energy saving lamp using a direct voltage source of the electricity grid as a comparison that includes the calculation of the magnitude of the voltage, current, frequency, power factor, and power consumed by energy-saving lamps.

f. Data testing of energy saving light using voltage PLN which includes the calculation of the amount of active power, apparent power, and reactive power.

In this activity will involve all the equipment to do a live test trial against indications of electrical quantities to be studied (measured) in this study. At this stage the deepening of the material to the settlement of the problem formulated. It also conducted the Search for literature and journals that support the research that comes out of print books, electronic books, and Internet access. The literature studies done to used as a guide information to support completion of data processing of research conducted experimental method. Information research study is indispensable for the implementation of the survey.
The study conducted through several stages of testing, measurement and analysis are as follows:

a. Prepare all the equipment that are used in this study.

b. Ensure that the accumulator would be used in full condition and ready to use.

c. Connect the DC ammeter in series with the positive terminal of the battery and the positive input terminal of the inverter.

d. Connect the parallel DC voltmeter (multimeter) to the battery terminal and inverter input terminal.

e. Measure the large voltages and currents that occur at the inverter input as well as a large measure inverter output voltage when the inverter is in a state of no load.

f. Connect the AC ammeters in series (can be replaced by a power meter) with one inverter output terminals and one terminal (cable) loads of energy saving lamps.

g. Connecting in parallel AC voltmeter (multimeter) and frequency meter to the inverter output terminals and terminal (cable) loads of energy saving lamps.

h. Turn on the inverter with the state of the load is a load with a large energy saving lamps predetermined light power (starting from the smallest firepower to the most massive).

i. Measure the primary input voltage inverter, inverter input current, the output voltage of the inverter, inverter output current, frequency and power factor inverter in a state loaded.

j. Repeatedly try (h) and (i) charge a significant energy saving light with another lamp power (lamp power raised to the extent desired).

$\mathrm{k}$. Note the results of measurements of the indicators obtained at the study table.

1. When it has finished measuring the whole load on the inverter, inverter shut off, releasing all the test series that has been 
assembled beforehand and store the equipment back in place of the original.

m. Analyze the calculation of some indicators that can not be obtained through measurements, such as large ignition computing based on the signal waveform, a large average voltage, the effective voltage, power input and power output of the inverter and the inverter efficiency at light loads with varying power.

n. Calculate the length of the charging current for the accumulator and the duration of use of the accumulator on the inverter.

o. Record all the results of measurements performed

\section{RESULT AND DISCUSSION}

This section describes the evaluation of the proposed work. Testing ignition circuit is the best way to understand the usage of the inverter. Ignition inverter circuit testing aims to see the waveform output from the ignition inverter control. Where the timer circuit is used to convert direct current DC into alternating current in a state $\mathrm{AC}$ voltage is less to be raised by a step-up transformer into a higher voltage. By using a digital oscilloscope that is connected directly to the ignition circuit inverter then obtained waveform as shown in the following figure.

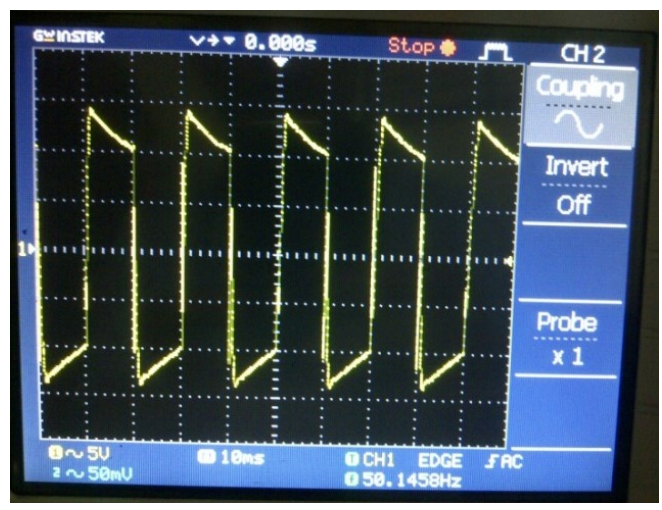

Fig.2 Form ignition circuit Wave Inverter

From the waveform above of the ignition circuit, the data obtained as follows:
Table 2. Data Testing Ignition circuit Inverter

\begin{tabular}{|c|c|c|c|c|}
\hline $\mathbf{V}_{\text {osc }}$ & $\mathbf{T}_{\text {osc }}$ & $\begin{array}{c}\text { Volt/div } \\
(\mathbf{V})\end{array}$ & Time/div (ms) & Probe \\
\hline 5,6 & 2 & 5 & 10 & $\mathrm{x} 1$ \\
\hline
\end{tabular}

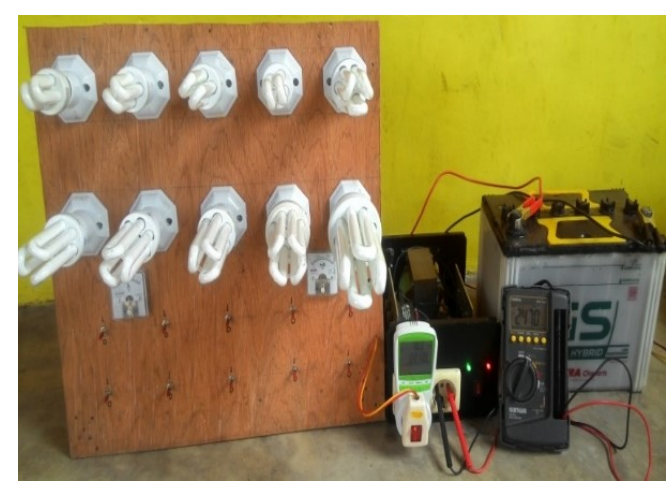

Fig. 3 Testing without load

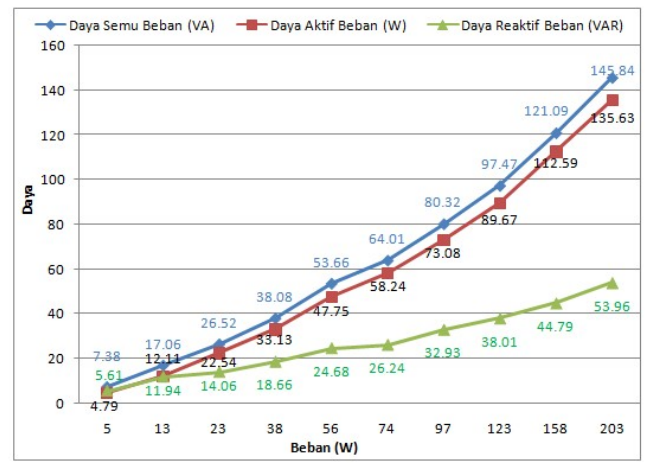

Fig. 4 Charges Against Pseudo Power, Active Power and Reactive Power Inverter Without load

Chart comparison between the load of the power consumption of the loads on the inverter and the power consumption of the load directly from the electric source (without inverter) is shown in the figure below.

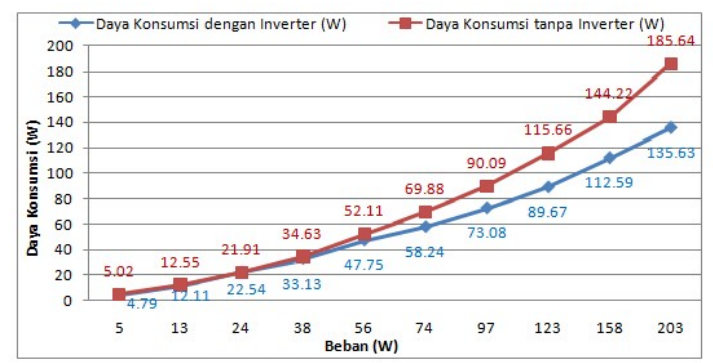


Fig. 5 Comparison of Charges Against Graph Power Consumption Without Load Inverters and Inverter

Chart comparison between the load of the reactive power by using inverters and reactive power directly from the electric source (without inverter) is shown in the figure below.

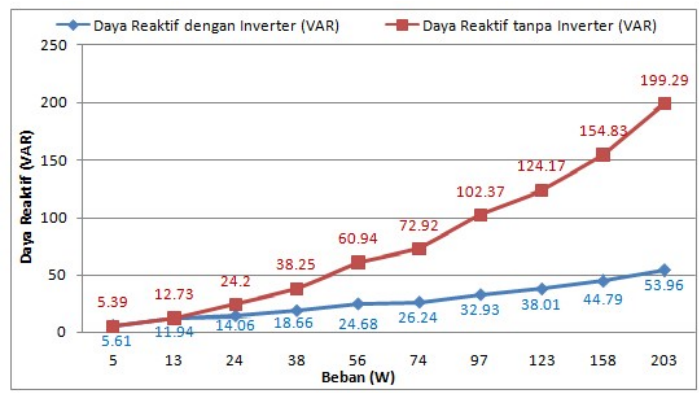

Fig. 6 Comparison Chart Expenses Charges Against Reactive Power Inverters and Without Inverter

\section{Conclusion}

The comparison brings much difference to the result. The load using the inverter and without inverter during the highest load is $203 \mathrm{~W}$; it can be concluded that $\operatorname{Cos} \varphi$ of the light weight by using an inverter so much better, reaching 0.93 compared with $\cos \varphi$ of the light load without using an inverter which is only 0.68 . The current consumed by lighting load using the inverter is much smaller compared to the current $0.76 \mathrm{~A}$ only destroyed the light weight without using an inverter which reached 1.3A. Active power (consumption) lamps using the much smaller inverter which is only $135,63 \mathrm{~W}$ compared with positive control (use) of the light load without using an inverter which reached $185.64 \mathrm{~W}$. Reactive power lamp using an inverter is much smaller with only 53.96 VAR reactive power load compared with light without using an inverter which reached 199.29VAR.

\section{REFERENCES}

[1] N. Kashappa and R. R. K., "Implementation of a Low Cost PWM Voltage Source Multilevel Inverter," International
Journal of Engineering and Technology Volume, vol. 2, no. 2, pp. 317-321, 2012.

[2] S. R. Ijjadal, S. V. S. Kumar, M. D. Reddy and S. A. Rahaman, "DESIGN OF LOW POWER AND HIGH SPEED," International Journal of Distributed and Parallel Systems, vol. 2, no. 5, pp. 127-135, 2011.

[3] O. O. Babarinde, B. S. Adeleke, A. H. Adeyeye, O. A. Ogundeji and G. A. L., "Design and Construction of $1 \mathrm{kVA}$ Inverter," International Journal of Emerging Engineering Research and Technology, vol. 2, no. 3, pp. 201-212, 2014.

[4] J. O. Coker and B. A. Ogunji, "Design and Construction of an Inverter Using Solar Cell as a Source of Charger," Journal of Applied and Natural Science, vol. 5, no. 1, pp. 30-36, 2013.

[5] M. Ahmad and B. H. Khan, "Design and Evaluation of Solar Inverter for Different Power Factor Loads, " Energy and Power Engineering, vol. 4, no. 1, pp. 324-329, 2012.

[6] S. A. Lawal and A. O. Michael, "Design, Construction and Performance Evaluation of 1KVA Pure Sine Wave Power Inverter," International Journal of Scientific \& Engineering Research, vol. 6, no. 3, pp. 1288-1303, 2015.

[7] Z. Tharo and A. P. U. Siahaan, "Profile Matching in Solving Rank Problem," IOSR Journal of Electronics and Communication Engineering, vol. 11, no. 5, pp. 73-76, 2016. 